\title{
ACOUSTIC ASPECTS OF RECONSTRUCION OF AN INDUSTRIAL BUILDING
}

Valéria V. Horn ${ }^{1}$

UDK: 534.832:725.4

DOI: 10.14415/konferencijaGFS2019.044

Summary: Functional changeing of a building involves the examination of building constructions concerning the requirements. In case of industrial buildings acoustic analyses are also essential. Accordingly to the new function the noise level in the operating rooms can increase. The main areas of the building acoustics test are: reducing the noise level in the room, protecting the rooms near the noisy room, limiting the noise emitted by the external building envelope structures, protecting the surrounding buildings against the summarized traffic and operational noise, checking of the designed structural changes with acoustic calculations to comply with the limits of standards.

Keywords: protection against operating noises, diffuse sound field, noise reduction, sound absorption, noise reduction

\section{INTRODUCTION}

During operation of a building, if a change occurs in the function, it must separately be examined whether the modification increase the noise level of the building environment. In this case, the floor plan of the building, the other rooms connected to the noisy room, the boundary structures and their sound insulation should be carefully analyzed. If the existing structures do not fulfill the requirements, then the structures have to be reconstructed. The article presents an example of this occasion.

In one of the residential area of Budapest built in with condominiums a locksmith plant operated in a one-storey building from the beginning of the 1950s. Due to change in function the plant had to be reconstructed to a carpentry workshop. Technological change meant a significant increase in noise pressure. The noise level generated at the plant and the transmitted sound power through the outer boundary structures space had to be reduced in order to keep the statutory limit values. The conversion required careful acoustic design.

The main areas of planning and control are:

1. Examining the original boundary structures of the carpentry workshop

2. Determining the noise level of the carpentry workshop

3. Reducing the operating noise of the carpentry workshop

${ }^{1}$ Valéria V. Horn, DLA, architect, assistant professor of Budapest University of Technology and Economics, Faculty of Civil Engineering, Department of Construction Materials and Technologies, H-1111 Budapest, Hungary, tel: +36146323 73, e - mail: horn.valeria@epito.bme.hu 
Савремена достигнућа у грађевинарству 23-24. април 2019. Суботица, СРБИЈА

4. Sound insulation of the modified facade structure of the carpentry workshop

5. Protecting adjacent rooms

6. Examining the noise level outside the building - Checking the noise load on the facade of a residential building across the street

\section{ORIGINAL BOUNDARY STRUCTURES OF A CARPENTER'S WORKSHOP}

The workshop was established in a sceleton-frame building covered with thermal insulated aluminum barrel-voult structure. The area of the workshop is about $140 \mathrm{~m}^{2}$, its clear height is nearly $4 \mathrm{~m}$, the area of the neighboring hand work-room is $60 \mathrm{~m}^{2}$. Near the carpentry workshop a hand work-room, warehouses and social rooms have been constructed and renovated. The building opens onto a U-shaped operating courtyard.

The facade wall of the carpenter's workshop were originally built of a double-layered channel-shape so-called kopolit profile glass, aluminum tilting windows and trapezoid plate cladding on the thermal insulated skirting.

On the one hand the interior space dividing structure is a $10 \mathrm{~cm}$ thick brick partition towards the dressing room of the factory and on the other hand a $30 \mathrm{~cm}$ thick aerated concrete wall towards the manual workshop and warehouse. An aluminum trapezoidal suspended ceiling was assembled above the workshop.

It can be stated that the sound insulation capacity and sound absorption of the original exterior space dividing structures is very small, therefore a new internal boundary had to be constructed. (Fig.1.)

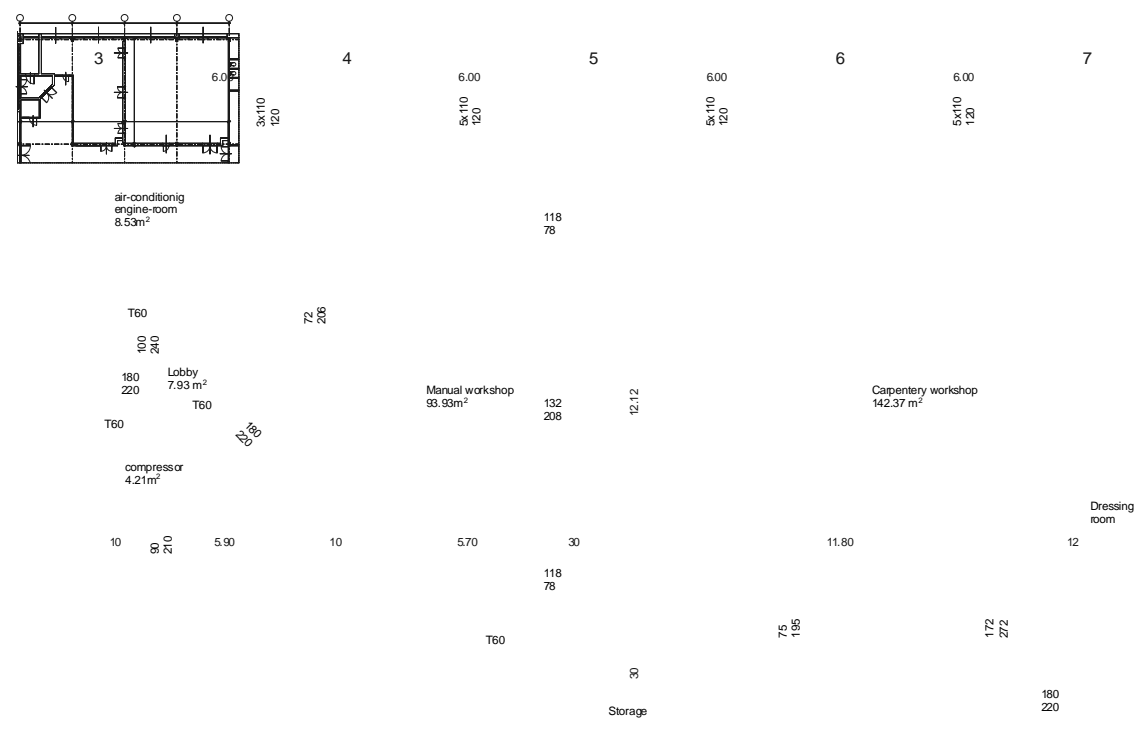

Fig. 1. Detail of ground-plan 
Contemporary achievements in civil engineering 23-24. April 2019. Subotica, SERBIA

\section{DETERMINING THE NOISE LEVEL OF A CARPENTER'S WORKSHOP}

The room of carpentry workshop has the largest noise level in the building. The workshop includes a band saw, two milling machines, a sliding panel saw, and a brush wheel grinder machine. Various machine replacements were investigated. The best of these arrangements was when the band saw is placed in the middle of the room. Another important aspect was the free circuity of the machines and ensuring of material handling.

The catalog data provided the A-weighted sound pressure level for the time of assessment for the machines. The sound pressure level of the band saw was determining, but the peak value of $\mathrm{C}$-weighted sound pressure of one of the milling machine reached $130 \mathrm{~dB}$. Moreover the sound pressure level of the band saw exceeds the noise exposure limit. It is not possible to reduce this level by building acoustic tools. The reduction was achieved with sound absorbing screens and canopies which were built above the machines.

In the carpenter's workshop, the resulting sound pressure levels were determined based on diffuse sound field approximation [1]. However, it had to be taken into account that noise is coming through the separating wall from the adjacent hand work-room:

$$
\text { LAres }=10 * \lg \left[\sum_{i=1}^{n} 10^{0,1 * L W A, i}+10^{0,1 * L W w}\right]+10 * \lg \left(\frac{4}{A e}\right)
$$

where the resulting $L_{\text {Ares }}$ is the industrial noise $(\mathrm{dB}), L_{W A, i}$ is the A-weighted sound pressure level corrected by the base noise of the machines $(\mathrm{dB}), \mathrm{L}_{W_{w}}$ is the transmitted noise through the wall of the hand work-room, $A_{e}$ is the equivalent sound absorbing surface $\left(\mathrm{m}^{2}\right)$ :

$$
A e=\sum_{1}^{n} \alpha i * S i
$$

where $\square_{\mathrm{i}}$ is the sound absorption coefficient of the surface, $S_{i}$ is the surface ( $\mathrm{m}^{2}$ ) belongs to the standard [2].

In addition to the original boundary structures, the level of $97 \mathrm{~dB}$ would have significantly exceeded the limit of the resulting operational noise level given in the decree [3].

\section{REDUCING THE OPERATING NOISE OF A CARPENTER'S WORKSHOP}

In the examination a diffuse acoustic model was taken, although the geometric dimensions of the workshop exceeded the size of diffuse spaces. However, due to the simultaneous use of machines, it was possible to use this acoustic model. Calculations were made for spatially changing (hall type) spaces and for different machine layouts, 
Савремена достигнућа у грађевинарству 23-24. април 2019. Суботица, СРБИЈА

from which very similar but lower noise results were achieved. That's why the diffusive acoustic model has become definitive.

Based on this specification, the upper intervention limits [3] are for daily noise exposure level to 8 hours of work: $\quad L_{E X, 8 h}=85 d B(A)$.

peak value for sound pressure (the highest value of the instantaneous sound pressure with a C-weighting filter): $\quad p_{\text {peak }}\left[L_{\text {max }}\right]=140 \mathrm{~Pa}[137 \mathrm{~dB}(\mathrm{C})]$.

One of the design tasks is to reduce the noise level below the $85 \mathrm{~dB}$ (A) intervention limit. Long-term exposure to higher noise than this value leads to hearing impairment [4].

Noise reduction could be achieved by creating a new structure independent of the existing parts. The sound absorption of the inner surfaces had to be increased. Since the sound insulation of the original external spatial limiting structures is low, the new structure must also have a significant sound barrier characteristic, in other words the spatial limiting element has double function. The task was solved with mounted assembled structures.

Single sided assembled wall

A single sided wall with double gypsumboard cladding was constructed as a soundinsulating structure in front of the lightweight steel purlin structure. On the existing side walls 100-mm-ridge gauge steel frame were assembled with $50 \mathrm{~mm}$ thick soft glasswool filling $\left(\rho=16-20 \mathrm{~kg} / \mathrm{m}^{3}\right.$, specific flow resistance $\left.r=6.5 \mathrm{kNs} / \mathrm{m}^{4}\right)$. This system is also constructed into the inner surfaces of the door opening.

The resulting soundproofing of the wall with the single sided assembled wall:

$$
\text { Rres }=R \text { wall }+\Delta R
$$

where $R_{\text {res }}$ is the resulting sound reduction index, $R_{\text {wall }}$ is the airborne sound insulation of the wall, $\Delta \mathrm{R}$ is the enhancement of the sound insulation of the single sided wall.

Horizontal ribs were placed on the gypsum plasterboard cladding of the single sided wall, with $5 \mathrm{~cm}$ thick, higher density $\left(\rho=40-50 \mathrm{~kg} / \mathrm{m}^{3}\right)$ glasswool plates with white glass veil filling, which ensures sound absorption from the interior space. The lower part of the front wall was protected by a $3 \mathrm{~mm}$ thick perforated hardboard up to a height of $2 \mathrm{~m}$ $(\alpha=0.60 ; \Delta \mathrm{Rw}=15 \mathrm{~dB})$.

Suspended ceiling

With the purlin system of the new structure the installation of suspended ceiling was easy. The plasterboard ceiling was fixed to suspended rods and had $5 \mathrm{~cm}$ soft glasswool ( $\rho=16-20 \mathrm{~kg} / \mathrm{m}^{3}$ ) filling, moreover a sound insulation improving FS-002S plate was inserted into the order of layer. PIRAMID FSP-35/70 sound absorbing polyurethane sheet was fixed to the bottom plane, which has excellent sound absorption at high frequencies $(\alpha=0.75$; improvement in sound insulation is $\Delta \mathrm{Rw}=15 \mathrm{~dB})$. 
$7^{\text {th }}$

INTERNATIONAL CONFERENCE

Contemporary achievements in civil engineering 23-24. April 2019. Subotica, SERBIA

Floor structure

The floor structure became floated. The existing substructure had to be demolished up to the plane of waterproofing. A $4 \mathrm{~cm}$ CDM-type vibration insulating plate layer was built on the top of the waterproofing. This floating layer was placed on the entire surface. Particular attention was required to carefully design the edges. A reinforced concrete screed was built above the floating layer, on which a resin gave the surface finish. (Fig. 2-3.)

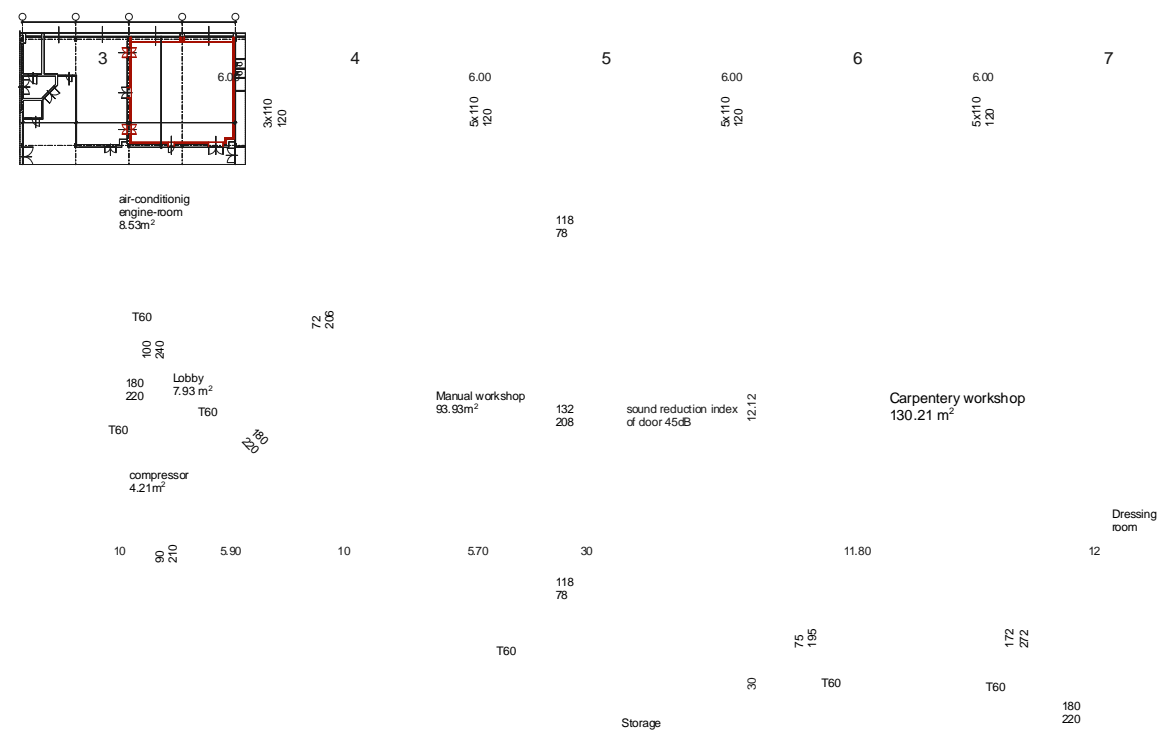

Fig. 2. Detail of modified ground-plan

Fig. 3. Modified sections 


\section{SOUND INSULATION OF THE MODIFIED FACADE STRUCTURE}

The original mounted façade had a very low Sound Reduction Index $\left(R^{\prime} w=29 \mathrm{~dB}\right)$. For this reason an assembled partition wall was built to improve the sound insulation. This was installed in front of the plane of reinforced concrete pillars with the 100-mm-ridge CW profiles which are covered on both sides with single-layer plasterboard and filled with $50 \mathrm{~mm}$ soft glasswool $\left(\rho=16-20 \mathrm{~kg} / \mathrm{m}^{3}\right)$. The sound insulation of the structure is $\mathrm{Rw}=49 \mathrm{~dB}$ based on standard DIN 4109 [5].

In the partition wall windows had to be placed in the same arrangement as the facade windows. The windows fulfilled the requirements with moderate sound reduction index $(\mathrm{R} \geq 37 \mathrm{~dB}$ ). The division of the windows were kept the same as the existing. An opening window was installed at every intervals. In front of the profile glass facade a steel-framed plasterboard partition was assembled.

Thus, the resulting sound reduction index of the facade:

$$
\text { Rres }=10 * \lg \left[\frac{S f * 10^{0,1 * R f}+\operatorname{Swin} * 10^{0,1 * R \operatorname{win}}}{S f+\operatorname{Swin}}\right]
$$

where $S_{f}$ is a solid part of the facade, $R_{f}$ is the Sound Reduction Index of the facade wall and the assembled wall together, $S_{\text {win }}$ is the surface of the window, $R_{\text {win }}$ is the Sound Reduction Index of the the original and the new window together.

Power level radiated through the facade to the plant:

$$
L w=L p-R^{\prime}+10 * \lg \left[\frac{S}{4}\right]+2
$$

where $L_{p}$ is the sound pressure level, $\mathrm{R}$ ' is the in situ Sound Reduction Index of the facade, $\mathrm{S}$ is the surface of the facade wall of the workshop, and the +2 factor is the factor increasing the in situ conditions [6].

\section{SAFETY OF ADJACENT ROOMS}

The carpenter workshop is neighbour with the dressing-room, the hand-held storage room and a handicraft workshop. The dressing room is only used before and after the start of the work, so it was not examined. There is no continuous work in the hand-held storage. However, there is working at the workshop at the same time as the carpenter workshop, so this room has to be protected from the sound insulation point of view.

The noise level is reduced through the facade to the other rooms facing the inner-court, it is about $10 \mathrm{~dB}$.

There are many handheld machines in the manual workshop that are not very loud. Their overall noise performance can only be estimated. Therefore, during the design, the total 
Contemporary achievements in civil engineering 23-24. April 2019. Subotica, SERBIA

power level was taken into account, that the sound power transmitted through the wall and the windows and the combined diffuse noise pressure level of the work here would be the permitted $\mathrm{LEX}_{\mathrm{E}, 8 \mathrm{~h}}=85 \mathrm{dBA}$ [3].

This room was also considered as a noise source with this $85 \mathrm{dBA}$ value. With the control measures less was detected.

Between the rooms there is a $30 \mathrm{~cm}$ wide aerated concrete wall. It was necessary to replace the doors between the two rooms, because in the wall originally two wooden delivery windows and a door were built with a simple wooden structure. The delivery windows could not be terminated from a technological point of view. These are the weak points of the wall structure, that is why they had to be transformed with openable wings from both sides. Around the wings there is a rubber sealing profile. The double-leaf door was counted with a significant $45 \mathrm{~dB}$ sound reduction (Lignifer). A hollow rubber profile had to be fixed to the wing.

\section{EXAMINATION OF THE NOISE LEVEL OUTSIDE THE BUILDING}

Limit values belonging to suburban area are taken into account. The District Noise and Vibration Protection Regulations do not contain any restrictions compared to National Regulations.

The noise load from industrial facilities and transport is limited by [7] as follows:

\begin{tabular}{|l|l|l|}
\hline Areas to be protected from noise & \multicolumn{2}{|l|}{$\begin{array}{l}\text { Limit value }\left(\mathrm{L}_{\mathrm{TH}}\right) \text { for the level of assessment }\left(\mathrm{L}_{\mathrm{Am}}\right), \\
\mathrm{dB}\end{array}$} \\
\cline { 2 - 4 } & $\begin{array}{l}\text { daytime } \\
6 \text { a.m. }-22 \text { p.m. }\end{array}$ & $\begin{array}{l}\text { night time } \\
22 \text { p.m. }-6 \text { a.m. }\end{array}$ \\
\hline $\begin{array}{l}\text { Residential territories } \\
\text { suburban area }\end{array}$ & 50 & 40 \\
\hline
\end{tabular}

The noise load limits for traffic noise in the various areas to be protected are given in [7]:

\begin{tabular}{|l|l|l|}
\hline Areas to be protected from noise & \multicolumn{2}{|l|}{$\begin{array}{l}\text { Limit value }\left(\mathrm{L}_{\mathrm{TH}}\right) \text { for the level of assessment }\left(\mathrm{L}_{\mathrm{AM}}\right), \\
\mathrm{dB} \\
\text { in closed areas between holiday homes, residential }\end{array}$} \\
& $\begin{array}{l}\text { buildings and public institutions; public areas } \\
\text { designated for relaxation }\end{array}$ \\
\cline { 2 - 3 } & $\begin{array}{l}\text { daytime } \\
6 \text { a.m. - 22 p.m. }\end{array}$ & $\begin{array}{l}\text { night time } \\
22 \text { p.m. }-6 \text { a.m. }\end{array}$ \\
\hline $\begin{array}{l}\text { Residential territories } \\
\text { suburban area (small town, } \\
\text { suburban territories, countrylike, } \\
\text { colonial) }\end{array}$ & 55 & 45 \\
\hline
\end{tabular}


Савремена достигнућа у грађевинарству 23-24. април 2019. Суботица, СРБИЈА

The permissible daytime noise level in the area was the limit during the examination. The night-time noise level did not have to be taken into account, as the workshop is operating only in daytime, in one shift.

The carpenter workshop opens to a relatively deep, 12x30 m yard. Counting on the multiple reflections of the sound which goes through the façade, the courtyard was also calculated with diffuse sound approximation. Noise transmitted not only on the façade but also on the roof had to be taken into account during the determination of the resulting noise level. Conversely, from the roof plane of the building sound power is counted as spread in free space.

The nearest building to be protected is a two-storey residential building across the street. The distance between the workshop and the residential building is $17.8 \mathrm{~m}$. (Fig. 4.)

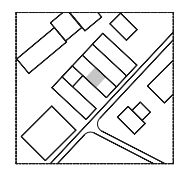

$$
\begin{aligned}
& \text { Factory building } \\
& \qquad \begin{array}{l}
\text { Factory building } \\
\text { Carpentery } \\
\text { workshop }
\end{array}
\end{aligned}
$$

Factory yard

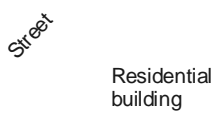

Factory building

Fig. 4 Site plan

The sound pressure level was calculated with a distance-dependent approach at an assessment point $2 \mathrm{~m}$ from the facade of the residential building [8].

$$
L p(r)=L w-20 * \lg r-10 * \lg \theta
$$

where $r$ is the distance of the test point from the spreading surface (m), $\Theta=2 \pi(\mathrm{sr})$ is the radial solid angle. The building to be protected has an operating noise load transmitted on the facade and roof of the industrial building. At this point, the industrial noise level was $40.9 \mathrm{~dB}$.

According to the noise map [9], [10], the traffic noise level in this area is $50 \mathrm{~dB}$. Thus, the result of operational and traffic noise [11]:

$$
L p r=10 * \lg 10^{(0,1 * L p t r+0,1 * L p f a c)}
$$


Contemporary achievements in civil engineering 23-24. April 2019. Subotica, SERBIA

where $\mathrm{L}_{\mathrm{pr}}$ is the resulting sound pressure level, $\mathrm{L}_{\mathrm{ptr}}$ is the traffic noise level, $\mathrm{L}_{\mathrm{pfac}}$ is the operating noise. On this basis, it can be stated that traffic noise is dominant.

\section{SUMMARY}

In conclusion, the noise load is below the limit value with the new, chosen structures.

After the workshop was rebuilt, acoustic measurements were performed during the phase of putting into operation. Measurements have proven that the designed and executed structure is appropriate.

\section{REFERENCES}

[1] VDI 2571 Sound Radiation from Industrial Buildings (In German) Schallabstrahlung von Industriebauten, Verein Deutscher Ingenieure, 1976

[2] MSZ EN 12354-6 Building acoustics Estimation of acoustic performance of buildings from the performance of elements - Part 6: Sound absorption in enclosed spaces, 2004

[3] Decree No. 66 of 2005 (XII. 22.) by the Ministry of Health on minimum health and safety requirements of noise exposition to employees at work (In Hungarian)

[4] Decree No. 65 of 1999 (XII. 22.) by the Ministry of Health on minimum health and safety requirements of employees' personal protective equipment at work (Annex 3) (In Hungarian).

[5] DIN 4109 Sound insulation in buildings; requirements and testing, German Institute for Standardization, 1989

[6] Reis F. Basics of building acoustics, (in Hungarian) Terc, Budapest, 2003

[7] 27/2008. Regulation (XII.3.) KvVM-EüM Joint Decree on the Establishment of Environmental Noise and Vibration Load Limits (Annex 1) (In Hungarian).

[8] MSZ EN ISO 12354-4 Building acoustics Estimation of acoustic performance of buildings from the performance of elements - Part 4 Transmission of indoor sound to the outside, 2018

[9] Budapest and its agglomeration strategic noise maps (In Hungarian) 2007

[10] Hunyadi Z., Juharyné Koronkai A., Reis F. Building acoustics, (in Hungarian) (lecture notes) Mủegyetem Kiadó, Budapest, 1999, lecture notes in BME, identification code 85017

[11]Fasold W., Kraak W., Schimer W., Acoustic Handbook (in German) Taschenbuch Akustik, VEB Verlag Technik, Berlin, 1984. 